\title{
Design and Implementation of An Improved Four Directional Automatic Solar Powered Street Lightning System
}

\author{
Ganiyu Adedayo Ajenikoko ${ }^{1}$ Adekunle Gideon Oluwafemi ${ }^{2}$ Bolarinwa Samson Adeleke ${ }^{3}$ \\ Okeniyi Samuel Olukunle ${ }^{4}$ Oluwagbenga Samson Omotosho $^{1} \quad$ Victor Tayo Ajiboye $^{1}$ \\ Muyiwa Arowolo $^{1} \quad$ Oguntuase Ayoola Ayodele ${ }^{1}$ \\ 1.Department of Electronic and Electrical Engineering, Ladoke Akintola University of Technology, P.M.B, \\ 4000, Ogbomoso, Nigeria \\ 2.Department of Electrical/Electronic Engineering, DS Adegbenro ICT Polytechnic, Itori-Ewekoro, Ogun State \\ 3.Department of Electrical Engineering, Adeseun Ogundoyin Polytechnic, Eruwa, P.M.B. 1015, Eruwa, Oyo \\ State, Nigeria \\ 4.Department of Technical Education, The College of Education, Lanlate, Oyo State
}

\begin{abstract}
Automatic street lightning system is very important particularly in urban and industrialized areas because of its ability to provide illumination and safety for vehicles and pedestrians throughout the night. It is relatively efficient as it consumes lesser amount of power with pre-determined operation times that are non-optimal for the surrounding environment. It is also a self-sustaining device. This research paper designed and implemented an improved four directional automatic street lightning system. It involved calculating the design parameters after selecting the appropriate devices and the cables. A solar street light is a form of renewable energy which is a standalone system in supply of electrical energy to be used for lightning. Solar radiation energy is used to charge the battery during daytime, and offer energy to the LEDs light equipment at night. A dimmable Modula is designed and integrated to the system to dim the LEDs at night from 01:00-06:00am. This system has a double advantage as it utilizes renewable energy and also reduces cost.
\end{abstract}

Keywords: Automatic, Four Directional, Solar Power, Renewable, Street Light, Utility Grids, Light Emitting Diodes (LEDs)

DOI: $10.7176 /$ JIEA/10-4-05

Publication date:September $30^{\text {th }} 2020$

\section{I.INTRODUCTION}

Solar street lights are widely used in lightning highways; roads; bridges; pedestrian streets and other occasions where lighting is required. Solar street lights according to their light sources are usually divided into Light Emitting Diodes (LED).Solar street lightning system is a set of separate and decentralized power supply system comprising of a solar lightning system. It is not subject to geographical restrictions and the locations of electrical installation. It does not require excavation of streets for burying pipes and power transmission and transformation systems, and the site construction and installation are very easy. It does not consume much electricity, it is energy-saving and environmentally friendly with comprehensive economic advantages particularly in economic application benefit in road lights far away from the grid, outdoor billboards and bus platforms..Solar street lightning system is composed of eight elements, the solar panels, solar battery, solar regulator, the solar tilt angle, foundation kit, solar head lamp, poles and cables [4],[5].

Solar street lightning system operating principle is simple. The solar panels with photovoltaic PV principles receive and convert solar radiation into electricity during daytime, and store electricity in batteries through charge controller. At night, once the illumination decrease to a set value, the batteries start to discharge. Solar street lightning is an effective way of reducing consumption of electricity. Each model of the street light is a paradigm of quality and innovation. Solar energy is a renewable source of energy, which is long-lasting and is pollution free. It can be utilized easily and is also cost effective in long term. Solar street light does not need staff for management and control and it can be easily installed in public places like hospitals, schools, streets etc. Light Emitting Diode (LED) lamp is generally used because of long life and energy saving (low watt). Light Emitting Diode (LED) street lamp is compact and shock resistive with energy efficiency[1],[5].

\section{A. Solar Street Light}

A solar light is a system for capturing and storing sunlight and then distributing it according to a pre-set-program. The production of solar street light has been associated with solar technologies which are broadly characterized as either passive or active depending on the way they capture and distribute sunlight. Active solar techniques use photovoltaic panels, pumps, and fans to convert sunlight into useful outputs. Passive solar techniques include selecting materials with favourable thermal properties, designing spaces that naturally circulate air, and referencing the position of a building to the sun. Active solar technologies increase the supply of energy and are considered supply side technologies, while the passive solar technologies reduce the need for alternate resources and are generally considered demand side technologies. A typical solar street light consists of 8 major components: solar 
panel, solar regulator, solar battery, the pole, casting, the tilt angle, solar head lamp and solar cable[2],[3].

\section{i. Solar Panel}

Solar panel is a device used to convert energy obtained from sun rays into electricity as shown in Figure 1. Solar panels are commonly called solar cells or photovoltaic cells. They create electric current and send it through output terminals as Direct Current (DC)[3].

\section{ii. Solar Regulator}

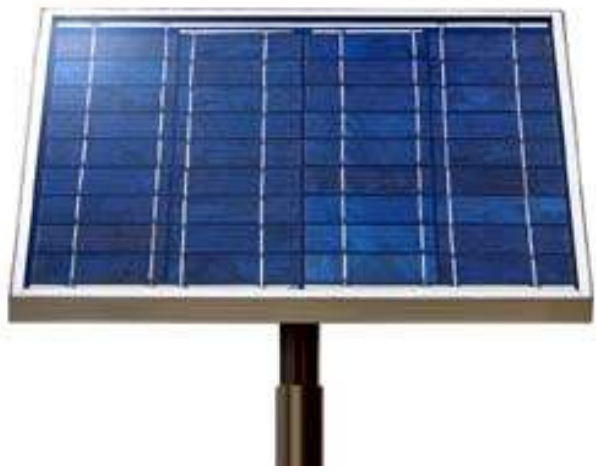

Figure 1: Solar Panel

A solar regulator is also called charge controller as shown in Figure 2. It is a device that modifies electric current that is added to or drawn from a battery bank. The Direct Current created by solar panels is sent through wire to the solar regulator. The solar regulator or charge controllers are rated by the amount of current they can receive from the solar panels[4]. The solar regulator can be grouped into three types namely: basic solar regulator (regulators designed to protect the battery from overcharging or undercharging and also prevents reserved current), Pulse Width Modulation (PWM) Solar Regulator (regulators that control the amount of current charging the battery and also trickle charge) and MPPT Solar Regulator (regulator that optimizes the power output from the cells and the battery charger to optimal capacity).

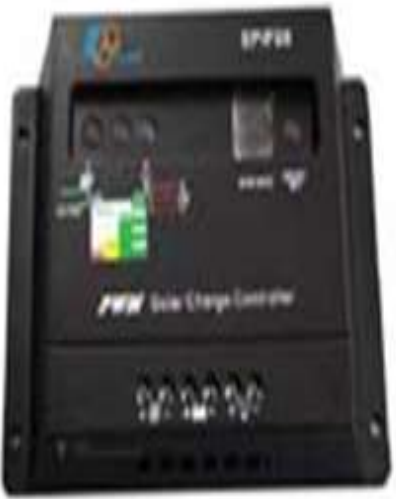

Figure 2: Solar Regulator

Solar regulator ensures that all the available power generated by a solar panel is stored efficiently in the battery bank, protect batteries from overcharging by lowering high voltage into lower voltage bank and during the night, a solar regulator prevents any reverse current flow from the batteries into the solar panel[1],[3].

iii. Solar Battery

The battery type selector switch allows the user to choose either gel or lead acid for a battery type, do not change the battery type switch while the batteries are connected to the controller. The battery is shown in Figure 3 . During the charging of the battery, LED lights thus indicating the charge cycle status. When the red light is ON, it indicates that the solar panel is properly connected and that solar power is being supplied. If the light is OFF, then there is none or insufficient voltage to activate the controller i.e. the battery is fully discharged.

When the blue light is ON, it indicates that the controller is in Bulk Charge Mode. This means the battery is charging and power is being allowed to pass through the battery. When the light is flashing, it indicates that the solar panel voltage is too low or there is insufficient sunlight. When the green light is $\mathrm{ON}$, it indicates complete charging on the battery. At this point, the battery is fully charged and the controller is in Float Charge Mode (Trickle Charging Mode). A small charge continues to pass to the battery in order to maintain a fully charged state[4]. 


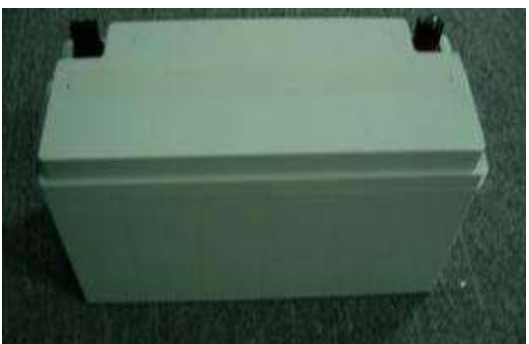

iv. The Pole

Figure 3: A Solar Battery

It is advisable to use an all in one kit on a pole shorter than $20 \mathrm{ft}$ and of 6 " diameter, a pole that can withstand any kind of wind during storm as shown in Figure 4[2].

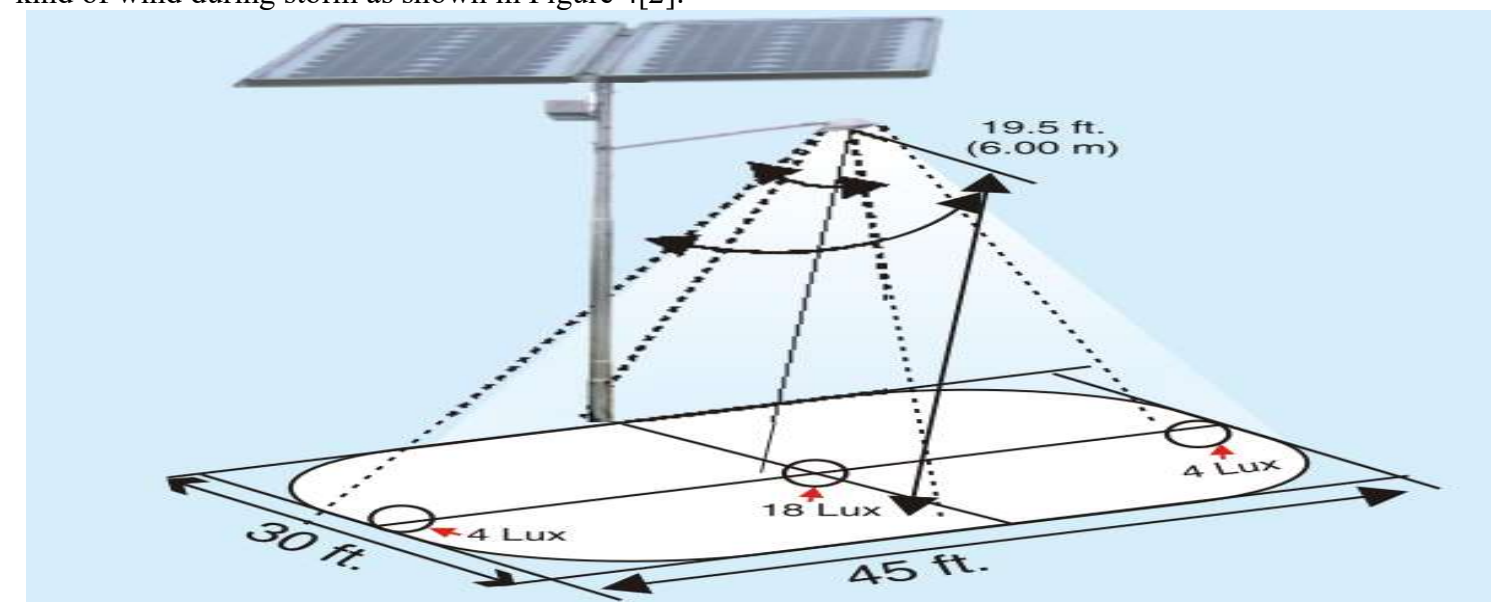

\section{v. Foundation Kit Setting}

Figure 4: Specification of Solar Street Light Poles

It is the digging of the foundation pit as the foundation drawing and mixing of the cement at the same time in which the photovoltaic cell (PVC) conduit is fixed to the anchor bolt to dig a small hole for the PVC conduit. Set the foundation kit and keep its template level. Plug both the PVC conduit to prevent debris or water into it, then pour concrete and keep the temple of foundation kit level. Clean the top of the foundation and smooth the face, then battery pit on the PVC conduit side after the concrete is solidified in 5-7 days. The foundation kit and the flange are shown in Figures 5a and 5b. Foundation Kits are easy to install and they have high strength steel rebar and stainless steel nuts[4],[5]

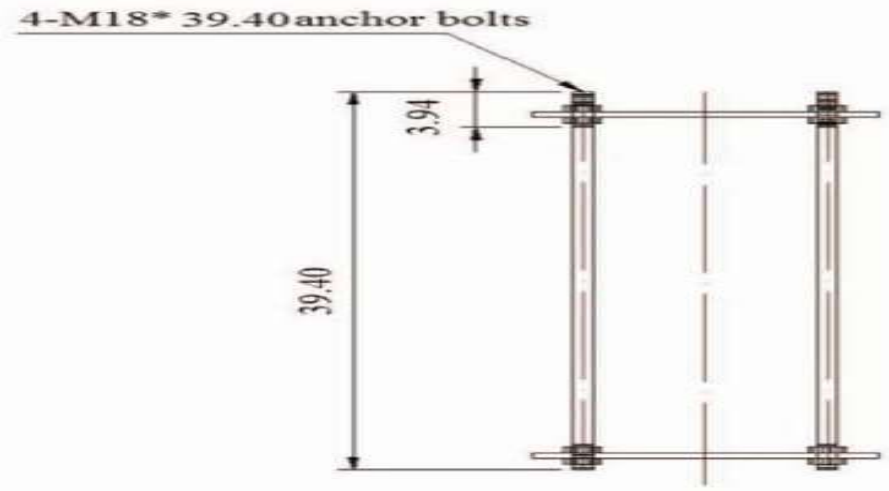

Figure 5a: Foundation Kit 


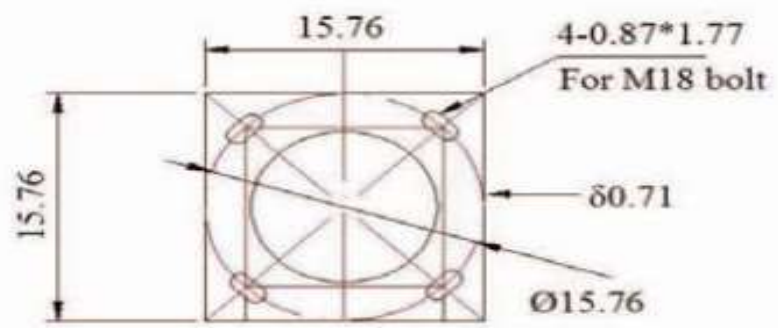

vi. $\quad$ Solar Head Lamp

Figure 5b: The Flange

In the construction of a solar street light, an LED head lamp is commonly used because of its feature cool white light without flickering and higher brightness than sodium lamps. The LED Head Lamp shown in Figure 6 has the benefits of long life estimated about 50,000+hours in operations (more than 11years at 12 hours a day), reduced maintenance due to long life, can withstand vibration from transport and rough weather, attractive cool white light, good efficiency-comparable with other lamps of same output and instant start (no warming up period)[2],[5].

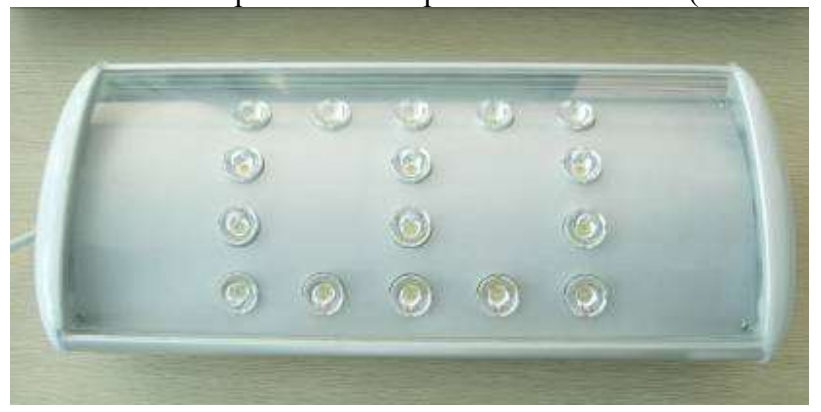

\section{B. Benefits of a Solar Street Light}

Figure 6: LED Solar Head Lamp

Solar Street light has some of the following benefits:[2],[4],[5].

i. Qualified for savings from various state and federal taxes and incentives.

ii. Savings on trenching, landscaping and maintenance costs and electric bills

iii. No power outages or single point of failure, ensuring enhanced security.

iv. Easy to install with quick connectors and does not require a certified electrician.

v. LED lamps feature cool white light without flickering and higher brightness than sodium lamps.

\section{MATERIALS AND METHOD}

All the calculations involved in the design and implementation of the solar street light, the concrete casting and mounting are analysed.

The relationship between Voltage, Current, Power and Resistance units is given as:

$$
\begin{aligned}
& P=V \times I \\
& V=I \times R \\
& I=\frac{V}{R} \\
& P=\mathrm{I}^{2} \mathrm{R}
\end{aligned}
$$

Where; $P$ is power, $V$ is voltage, $I$ is current and $R$ is resistance.

The amount of energy required to determine the size and power of the headlamp is given as:

Electrical usage in watts per day = Energy consumed by the device per day in watt-hours/daily energy. (5)

Daily Energy =Appliance power rating in watts $x$ Quantity $x$ Working or Usage in hour

The appliance to be powered is four (4) 13.2 watts solar LED head lamp and it will be powered between $7 \mathrm{pm}-6 \mathrm{am}=11$ hours

The electrical usage in watts per day $=13.2$ watt $\times 4 \times 11=580.8$ watthour/day

The size of solar panel is calculated as:

$$
\begin{aligned}
& \text { Number watts of solar panel }=\frac{\text { Electrical usageinwatts } / \text { day }}{\text { Insolationint }} \\
& \text { Number watts of solar panel }=\frac{396}{\text { Insolationoftheare }}
\end{aligned}
$$
be used.

Therefore a solar panel of at least $130 \mathrm{watt} 20 \mathrm{~V}$ which is the closest value to the calculated value that can 
The sizing calculation is:

$$
\begin{gathered}
\mathrm{C}=\left(\frac{E \times h}{d}\right) \div V \\
d=\frac{\text { battery charge point - battery discharge point }}{\text { battery charge point }} \times 100
\end{gathered}
$$

Where:

$C=$ Battery capacity in ampere-hours (Ah)

$E=$ Daily energy requirement in $\mathrm{Wh} /$ day

$h=$ Holdover in days $=1$

$d=$ Depth of discharge expressed as a decimal

$V=$ System voltage

Therefore, a 200Ah battery is needed for this 52.8watts LED head lamp to be powered for complete 11 hours.

The selection of the controller is determined by four factors; the system voltage, the solar array (input) current, the load (Head lamp / output) current and the type of battery. If it is not possible to find a controller with the correct specifications, then it may be necessary to change the system voltage and repeat the sizing calculations.

The head lamp power $=52.8$ watts at $12 \mathrm{~V}$

Headlamp current $=\frac{\text { thelamppowe }}{\text { operatingvoltage }}=52.8 / 12=4.4 \mathrm{Amp}$

For battery type, a 10amp solar regulator can be selected since the solar array maximum current and the load current is less than 10Amp but greater than 5Amp.

The cable sizing is calculated as:

$$
A=\frac{\mathrm{Lx} \text { I } 0.04}{\mathrm{~V}}
$$

Where:

$$
\begin{aligned}
& A=\text { Cross-sectional area of the cable in } \mathrm{mm}^{2} \\
& L=\text { Length of cable in metres } \\
& I=\text { Current in Amperes } \\
& V=\text { Maximum permissible voltage drop in Volts }
\end{aligned}
$$

The maximum permissible voltage drop should be $5 \%$ of the system voltage, which are $0.6 \mathrm{~V}$ for a 12 Volt system and $1.2 \mathrm{~V}$ for a 24 Volt system.

The solar street light pole needs to be dimensioned based on the size/ lumen, geographical location and the size of the solar module to be on the pole. The diameter of the pole needs to be calculated and the height of the pole also needs to be calculated. The right size of the pole has to be used unless the pole will collapse during or after the mounting of the pole and the devices to be installed on it.

The foundation kit and casting is a device made up of four metal rod with screw head and eight small metal brace arranged (weld) in a rectangular shape. The specification of the components used in this study is depicted in Table 1 and the connection of the components is shown in Figure 7.

Table 1: Components Specification

\begin{tabular}{lll}
\hline Components & Specification & QTY \\
\hline Pole & Iron-spray-paint on surface Height: 20ft, Pole thickness: 6’, & 1pcs \\
Solar Panel & 200W, 20V & 2pcs \\
Storage Battery & $12 \mathrm{~V} 100 \mathrm{AH}$ & $2 \mathrm{pcs}$ \\
Controller & $12 \mathrm{~V} 10 \mathrm{Amp}$. & $1 \mathrm{pcs}$ \\
Lamp & $13.2 \mathrm{~W}$, warm white LED & $4 \mathrm{pcs}$ \\
Arm & Length 18ft & $4 \mathrm{pcs}$ \\
Solar panel Bracket & Bracing frame: 1pc T link bracket: 1pc & $4 \mathrm{pcs}$ \\
& V bracket: 2pcs & $5 \mathrm{pcs}$ \\
Groundwork Stand & Dead plate: 1PCS; Iron post: 4PCS & $2 \mathrm{pcs}$ \\
Storage Battery Box & Metal steel plate box & \\
Others & Wire fastener, solar cables & \\
\hline
\end{tabular}




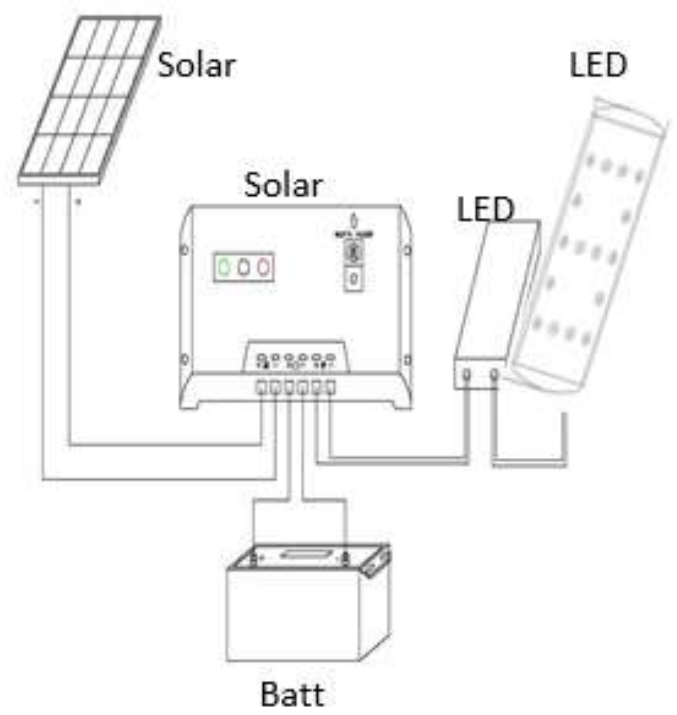

Figure 7: Connection of the Components

\section{III.IMPLEMENTATION AND TESTING \\ i. Implementation}

During the installation, the safety of the installers and public was considered.

Although, solar powered systems are generally of low voltage, the wiring regulations for the installation was obeyed. The installation of the solar array was determined by the type of support structure which was completed in three stages. In addition, before fixing to the roof or ground, the solar panels was mounted to the support rails to create a single unit. In larger systems the solar array may be split into sub-arrays. Each of these is treated as a separate solar array.

It was very easy to connect the individual solar panels together and the long output cable to them before putting them into position, especially if they were to be roof mounted. Connection of all the solar panels together first; either in one, two or four groups depended on the system voltage. All connections were properly checked before replacing the terminal box .

Installation of the battery was as simple as taking a wet-charged or sealed battery out of a box and placing it on a firm level surface. Alternatively, it involved mixing acid in the right concentration and filling the batteries on site. The batteries needed to be mounted such that they were secured, i.e. they couldn't fall over and they were protected from unauthorised access and away from sources of ignition. The room or container that they were in was ventilated so as to allow the hydrogen produced by charging to escape. This applied even to sealed batteries as they were able to vent excess gasses should the charging system malfunction. Once the battery had been put in place, the individual batteries or cells was connected together to form a single battery.

\section{ii. Testing}

It was the best to test the solar array before mounting to avoid having to take it down again. To do this, it was turned over and laid on the ground with the face up. The voltage between the two cores of the output cable was measured using a multi-meter. It was equivalent to the open-circuit voltage of one solar panel multiplied by the number of solar panels in series. That is, about $20 \mathrm{~V}$ for a $12 \mathrm{~V}$ system, $40 \mathrm{~V}$ for a $24 \mathrm{~V}$ system and $80 \mathrm{~V}$ for a 48 $\mathrm{V}$ system. 80 Volts is a dangerously high voltage, and 40 Volts is enough to give a nasty shock in the wrong circumstances. Adequate care was taken when performing these measurements and the solar array was covered with an opaque material before connecting the meter.

Once this test was complete, the solar array was made safe before lifting it into place. There are two ways of doing this; either cover it with an opaque material or connect the cores of the output cable together to short-circuit the solar array. This would not cause any damage and was the preference chosen. Usually there were a number of rails mounted to the roof or foundations first. It was ensured that these are orientated correctly so that the solar array would point towards the equator once mounted; that is towards the south in the northern hemisphere and towards the north in the southern hemisphere. The different battery voltages are shown in Figure 8 to Figure 11. 


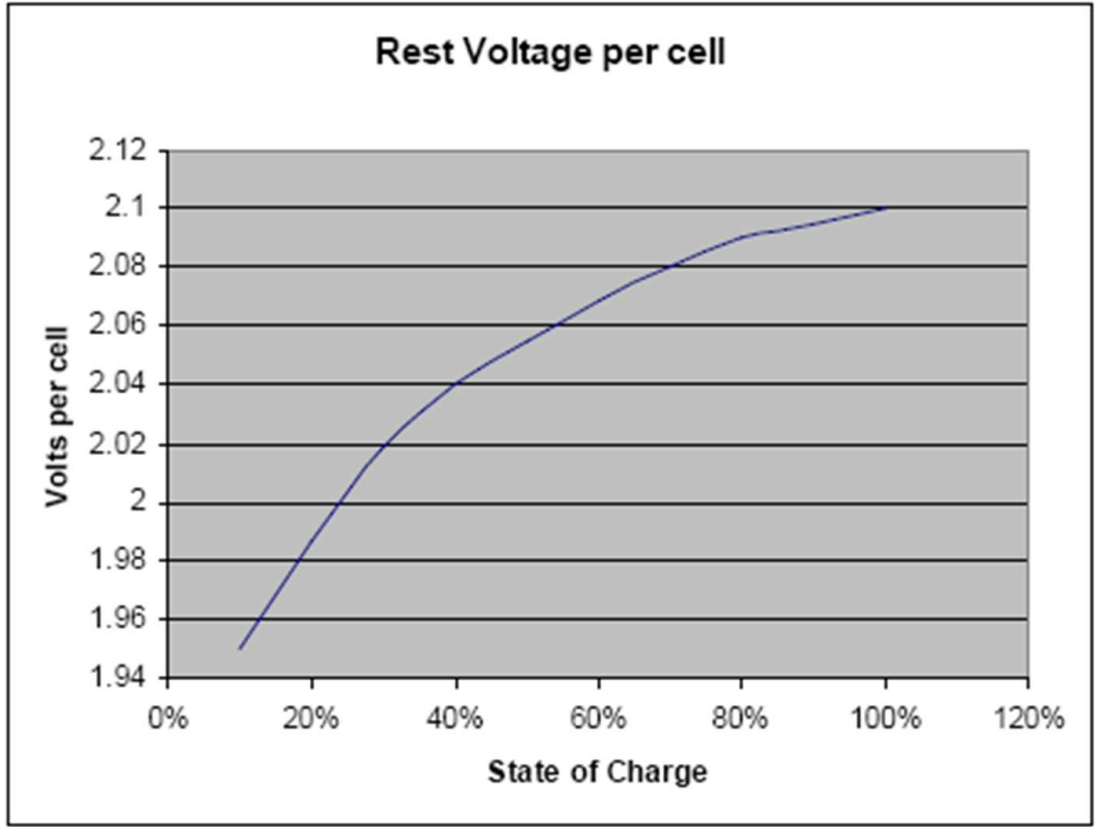

Figure 8: Voltage per Cell versus State of Charge

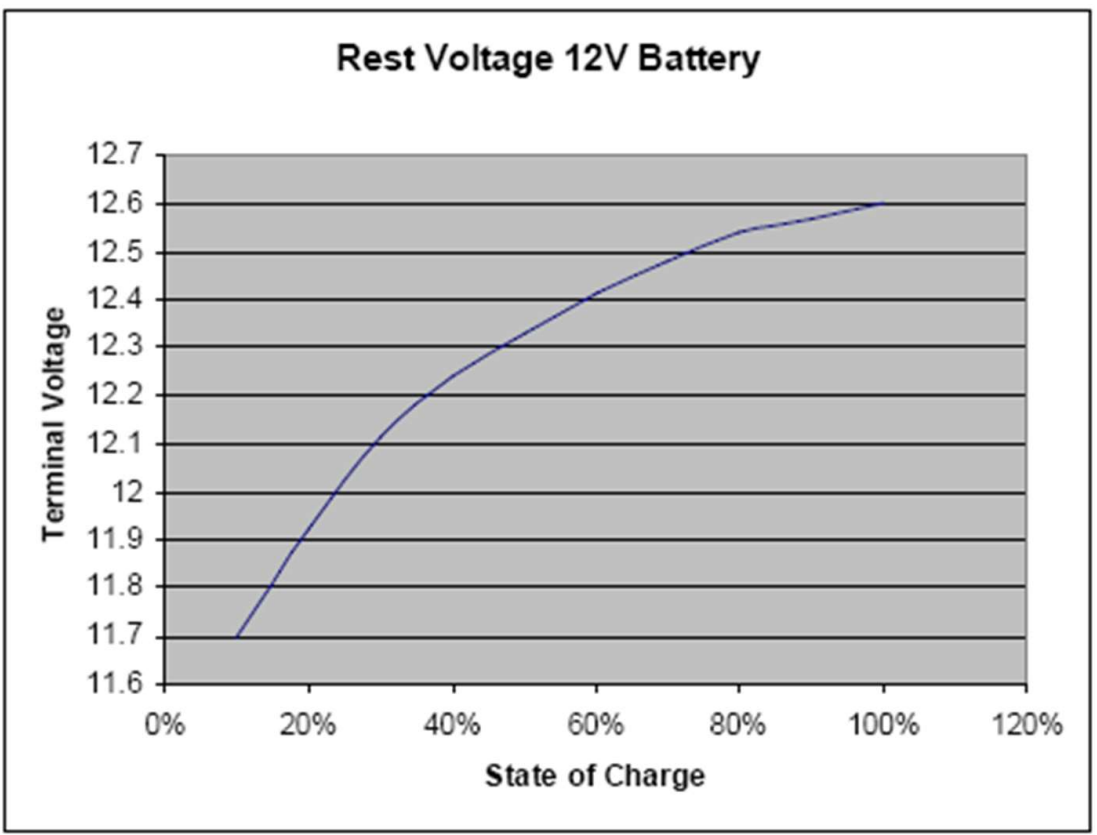

Figure 9: Terminal Voltage versus State of Charge 


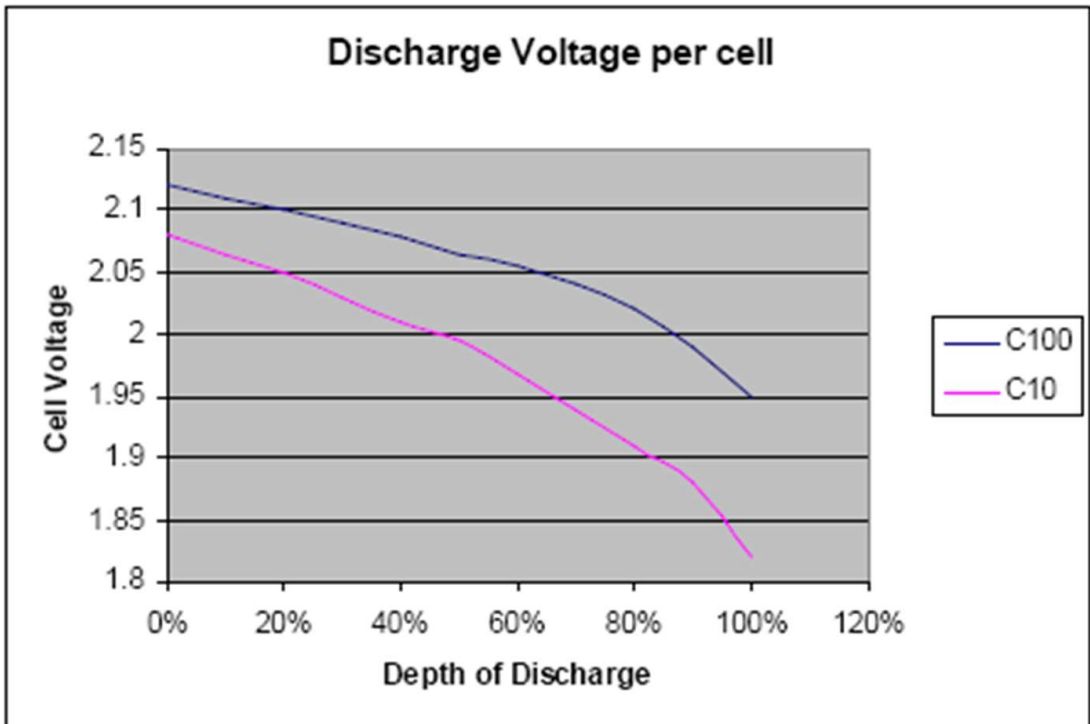

Figure 10: Cell Voltage versus Depth of Discharge

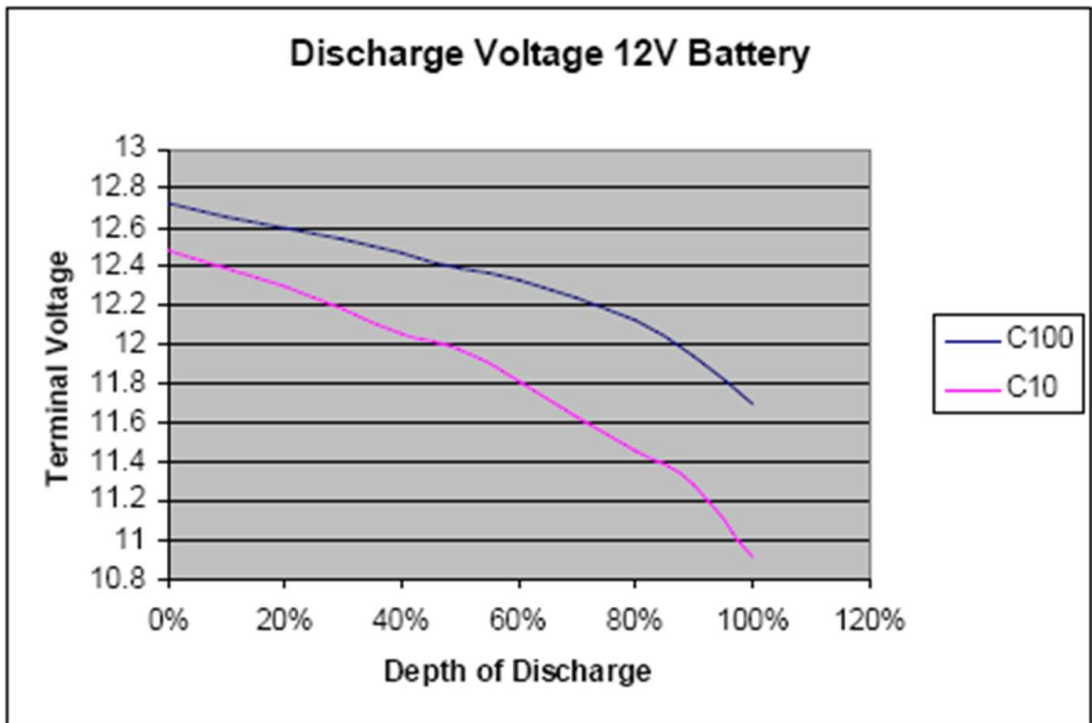

Figure 11: Terminal Voltage versus Depth of Discharge

\section{IV.CONCLUSION}

The design and implementation of an improved four directional automatic solar powered street lightning system has been presented. This involved calculating the design parameters after selecting the appropriate devices and the cables. A solar street light is a form of renewable energy which is a stand-alone system in supply of electrical energy to be used for lightning. From this research paper, it was obvious that a solar street light cannot work on its own without the use of charge controller which basically works to provide regulation and determines when the battery is fully charged and to avoid over charging.

This solar street light with thorough calculations and correct selections of materials with proper installation can be recommended for use in cities and rural areas of the country.

\section{REFERENCES}

[1] Liu, G. (2014). "Sustainable feasibility of solar photovoltaic powered street lightening system" Electrical power and Energy system,Vol. 5, No. 9, Pp 168-178.

[2] Mehta, V. K. (2013). "Principles of Electronics.", Second Edition,.chand S and Company Ltd, India.

[3] Siddhartha Bhatt, M. (2016). "Solid state (LED) lighting technology-Overview", International Journal of Electrical Engineering, Vol. 5, No. 6, Pp. 58-65. 
[4] Singh, S. N. and .Singh, A. K (2017). "Techno-Economic Viability of the hybrid solar photovoltaic (PV)-AC Utility interfaced Power system for rural India”. The journal of CPRI (India) Vol. 3, No.1.Pp, 1-10.

[5] Singh, S.N.(2018). "Intelligent Home Energy Management by Fuzzy Adaptive Control Model for Solar(PV)grid/DG Power System in India“. IJPCSC, Vol. 2, No1, pp 61-66. 